\title{
Clínica y Salud (1998-2008). Análisis de Diez Años de Publicaciones
}

\section{Clínica y Salud (1998-2008). An Analysis of Ten Years of Publications}

\author{
Francisco Pérez Fernández \\ Universidad Camilo José Cela (Madrid)
}

\begin{abstract}
Resumen. Clínica y Salud no sólo se ha convertido con el paso de los años en una publicación de referencia en el entorno de la psicología española sino que, a la vista de los datos que hemos podido recabar, y cuyo análisis se ofrece en este trabajo, es también una revista científica saludable y con un prometedor futuro. Ya parecía encontrarse en esta línea ascendente hace una década, momento en el que se realizó el primer estudio bibliométrico de la publicación que recogía la andadura de los siete primeros años de su existencia. En consecuencia, parecía pertinente comprobar ahora si aquellos primeros éxitos fueron un espejismo o el principio de la consolidación. Es precisamente al estudio y verificación de este hecho que dedicamos el presente trabajo de análisis bibliométrico esperando, asimismo, que sea útil para extraer conclusiones que permitan a Clínica y Salud, a su equipo editorial y a sus afines, continuar creciendo en el futuro.
\end{abstract}

Palabras Clave: Revista Clinica y Salud, análisis bibliométrico.

\begin{abstract}
Clínica y Salud has not only become over the years a publication of reference in the context of Spanish psychology but also, in view of the data that we have collected and their analysis carried out in this article, a scientific journal with a healthy and promising future. This upward trend already seemed to be emerging a decade ago, when the first bibliometric study of the publication was made, dealing with the first seven years of its existence. Therefore, it seemed appropriate to check now if that early success was an illusion or really the beginning of a period of consolidation. Indeed, it is to studying and verifying this that we dedicate this bibliometric analysis. In this way we also hope that it will prove useful in order to draw conclusions and allow Clínica y Salud, its editorial team and all involved with the journal to continue growing in the future.
\end{abstract}

Key words: Journal Clínica y Salud, Bibliometric annalysis.

\section{Introducción}

Es evidente que la práctica clínica ha venido siendo el ámbito de ocupación profesional preferencial para la profesión psicológica (Santolaya, Berdullas y Fernández, 2001), por lo que la aparición de una revista científica en este campo, que obrara como

La correspondencia sobre este artículo dirigirla al autor: Departamento de Psicología y Educación. Universidad Camilo José Cela. C/ Castillo de Alarcón, 49. Villafranca del Castillo, 28692 Madrid.e-mail:fperez@ucjc.edu órgano de expresión del Colegio Oficial de Psicólogos al respecto, se convirtió muy pronto en una cuestión de principio. La diversidad de escuelas y los problemas profesionales, especialmente los del entorno privado, eran una realidad que requería de la implicación activa del psicólogo clínico dentro del colegio, de modo que se pensó en una revista como medio de unificación de criterios y forja de una

Este trabajo se adscribe al proyecto de investigación SEJ200605229. 
identidad profesional concreta (Pérez, 2008). De tal modo, la publicación antecedió curiosamente a la creación de la Sección de Psicología Clínica del Colegio Oficial de Psicólogos, que quedó establecida tras el pertinente proceso electoral en 1996 (García Higuera, 1997).

Clínica y Salud comenzó su andadura en 1990. Ya en 1997 se publicó un primer trabajo de análisis bibliométrico que analizaba la revista en su primer tramo de desarrollo (Aláez, 1998). Desde entonces han pasado diez años y, creemos, ha llegado el momento de establecer un segundo hito que nos permita observar detenidamente el desarrollo que ha seguido la revista tras su primera fase, que podemos considerar como de consolidación.

\section{Métodología}

Para nuestro análisis, junto con los datos recabados en el estudio de la propia publicación, nos hemos apoyado en la medida bibliométrica por los elementos de juicio arrojados por el Índice de Impacto de Revistas Españolas en Ciencias Sociales (IN-RECS $)^{1}$, en tanto que uno de los criterios fundamentales reconocidos para la evaluación de la ciencia y de la comunidad científica. IN-RECS comienza a valorar datos del universo de revistas de psicología españolas a partir de 1996 y se encuentra actualizado hasta el año 2007, con lo que cubre nuestro tramo temporal prácticamente por entero.

Del mismo modo, volveremos en su momento al estudio de Aláez anteriormente referenciado, especialmente a la hora de valorar la evolución de la temática de los artículos publicados en Clínica y Salud, a fin de establecer la pertinente comparativa.

${ }^{1}$ http://eg3 .ugr.es/in-recs/
El método de recopilación de información, dados los fines fundamentalmente descriptivos de la primera parte de este trabajo, se ha basado en una revisión de títulos, autores, palabras clave y se ha atendido a los resúmenes sólo en aquellos casos en los que las otras fuentes no nos permitían establecer conclusiones precisas acerca de los contenidos de los artículos. En consecuencia, se han seguido los pasos siguientes:

1. Recuento de artículos publicados en total, así como desglosado por años.

2. Recuento de autores y firmas.

3. Clasificación de los trabajos por temáticas. En una primera fase se ha seguido un criterio amplio y, posteriormente, se ha reducido el marco categorial a los siete criterios del anterior trabajo de Aláez a fin de que este estudio guarde, como ya se indicó, continuidad con el precedente.

4. Temas por años. Nos ha parecido relevante establecer esta panorámica, prestando especial atención a determinados sucesos relevantes acontecidos en el ámbito de la psicología clínica, a fin de que el lector pueda hacerse cargo de la evolución temática seguida por la revista a lo largo del tiempo.

\section{Datos recogidos y análisis descriptivo}

Entre 1998 y 2008, Clínica y Salud ha publicado un total de 178 artículos, lo cual conduce a una media interanual de 15,4 publicaciones. El año en el que aparecieron más trabajos fue 2007 (24), curiosamente el mismo año en el que se produjeron cambios sustanciales en el consejo editorial de la revista, mientras que el año en que se publicaron menos fue el 2000, con 12 (gráfico 1).

Gráfico 1. Evolución interanual de publicaciones y media

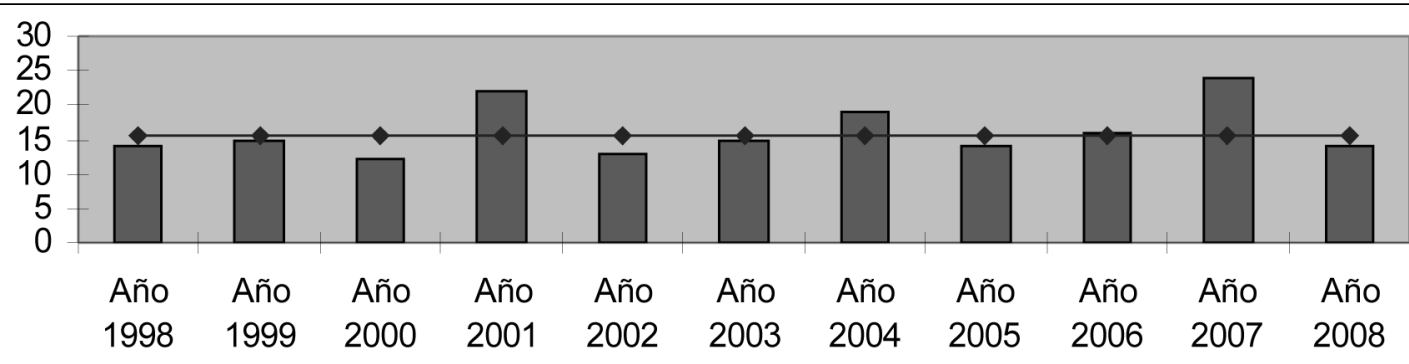


Gráfico 2. Reparto porcentual de autores/as por firmas

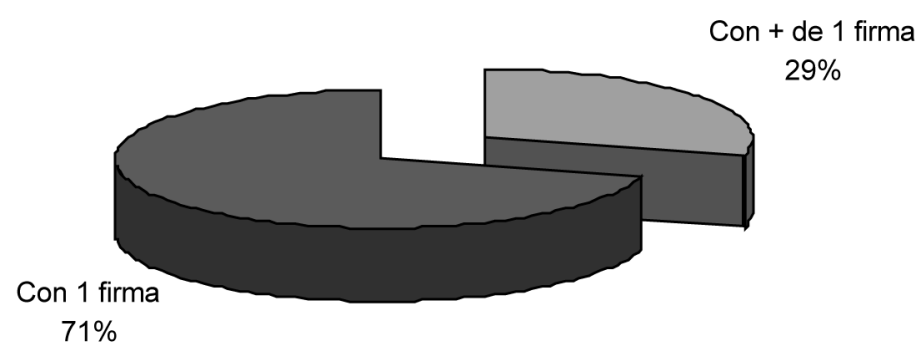

Gráfico 3. Autores/as con más de una firma. Porcentajes relativos

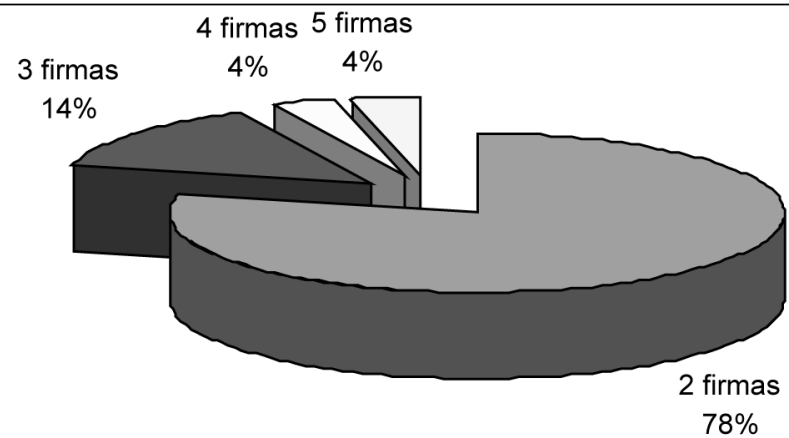

Tabla 1. Autores/as y firmas

González Ordí, H.

Sanz Fernández, Jesús

Carrillo, Jesús

Portellano, Jose Antonio

Barrio, Victoria del

Fernández Montalvo, Javier

Martínez Arias, Rosario

Perona, Salvador

Prieto Ursúa, María

Rojo, Nieves

Vázquez, Carmelo

Vázquez, Fernando

$\mathrm{N}^{\circ}$ de autores/as con dos firmas $=45$

$\mathrm{N}^{\circ}$ de autores/as con una firma $=326$

5
5
4
4
3
3
3
3
3
3
3
3
90
326

TOTAL $=383$

TOTAL $=458$

En cuanto al número de publicantes, han sido 383 los autores/as de los trabajos aparecidos en el periodo estudiado, lo cual establece un índice de coautoría bastante elevado (2,2 autores por ítem publicado), si bien el número de firmas alcanza las 458 como consecuencia de las repeticiones de autoría. De hecho, son 57 los autores/as que han publicado más de un trabajo. De entre ellos 12 más de dos, y son 4 los que firman en más de tres ocasiones. En total, los 57 autores que han repetido publicación dan cuenta de 132 de las firmas aparecidas (Gráficos 2 y 3; Tabla 1). Estos datos no sólo implican que Clínica y Salud tiene, como resulta esperable en una publicación de carácter científico, un elevado número de autores transeúntes, sino que también reproduce con bastante eficiencia el modelo general de la ley de Lotka. Así, un 29\% de autores/as aparece en el $43 \%$ de los artículos publicados, entretanto el $71 \%$ restante sólo lo hace en un $57 \%$ de los ítems.

Debe hacerse notar en este punto, y como conse- 
cuencia directa de los datos precedentes, que la correlación entre visibilidad y cantidad de publicaciones es elevada pues cinco de los autores/as que han firmado más de un trabajo en el periodo estudiado han logrado, del mismo modo, que alguno de sus artículos se encuentre entre los diez más citados de Clínica y Salud a partir de 1998 (Tabla 2), lo cual los sitúa en el frente de investigación del campo. aplicación y/o validación de tests e instrumentos de evaluación).

3. Terapia e intervención clínica (psicoterapia, diseño de tratamientos, estudios de casos, informes clínicos, rehabilitación).

4. Investigación (epidemiología, estudios experimentales, evaluación de necesidades, evaluación de programas).

5. Psicología de la salud (intervención en trastor-

Tabla 2. Autores/as con más de una firma entre los más citados durante el periodo 1998-08

Sanz, Jesús
Vázquez, Carmelo
Barrio, Victoria del
Fernández Montalvo, Javier
Barajas Martínez, S.

TOTAL
5 firmas / 27 citas

3 firmas / 27 citas

3 firmas / 19 citas

3 firmas / 8 citas

2 firmas / 7 citas

16 firmas / 186 citas
En cuanto a la temática de los trabajos publicados a lo largo del tramo temporal que cubre este estudio, clasificada desde un marco categorial amplio apoyado en el análisis de títulos y palabras clave, hemos podido realizar un muestreo general de los artículos tal y como se observa en la tabla 3 . nos y estados físicos, medicina conductual, educación para la salud, programas de prevención).

6. Revisiones (categorías clínicas o trastornos, historia).

7. Temas profesionales (relatos de profesionales, formación del psicólogo clínico y de la salud,

Tabla 3. Artículos publicados por temas

\begin{tabular}{|c|c|}
\hline Trastornos & 37 \\
\hline Revisión teórica & 29 \\
\hline Instrumentos para psicodiagnóstico & 26 \\
\hline Personalidad & 13 \\
\hline Estudio de casos & 13 \\
\hline Intervención & 12 \\
\hline Evaluación psicológica & 8 \\
\hline Emoción & 8 \\
\hline Servicios de intervención & 5 \\
\hline Psicofisiología & 4 \\
\hline Actualidad de la psicología clínica & 3 \\
\hline Psicoanálisis & 3 \\
\hline Estilos cognitivos & 2 \\
\hline Entrevista & 2 \\
\hline Congresos / Jornadas & 2 \\
\hline Prevención & 2 \\
\hline Otros & 9 \\
\hline TOTAL & 178 \\
\hline
\end{tabular}

Atendiendo al criterio de Aláez (1998), y a fin de poder establecer comparativas con el primer estudio, podemos reagrupar los trabajos en siete categorías fundamentales:

1. Trabajos teóricos (reflexión, conceptuales, epistemológicos y metodológicos).

2. Evaluación psicológica (psicodiagnóstico, servicios de intervención, interdisciplinariedad, documentos institucionales).

El gráfico 4 muestra la pertinente comparativa entre la muestra temática de los artículos del periodo 1990-97 y los del estudiado en este trabajo que permitirá al lector observar, en líneas generales, la evolución que ha seguido Clínica y Salud. 
Tabla 4. Artículos publicados por temas clasificados siguiendo el criterio de Aláez (1998)

Trabajos teóricos

Revisiones

Terapia e intervención clínica

Evaluación psicológica

Investigación

Psicología de la salud

Temas profesionales

\section{8}

38

34

26

9

TOTAL

Gráfico 4. Comparativa entre el período 1990-97 y el período 1998-08 (\%)

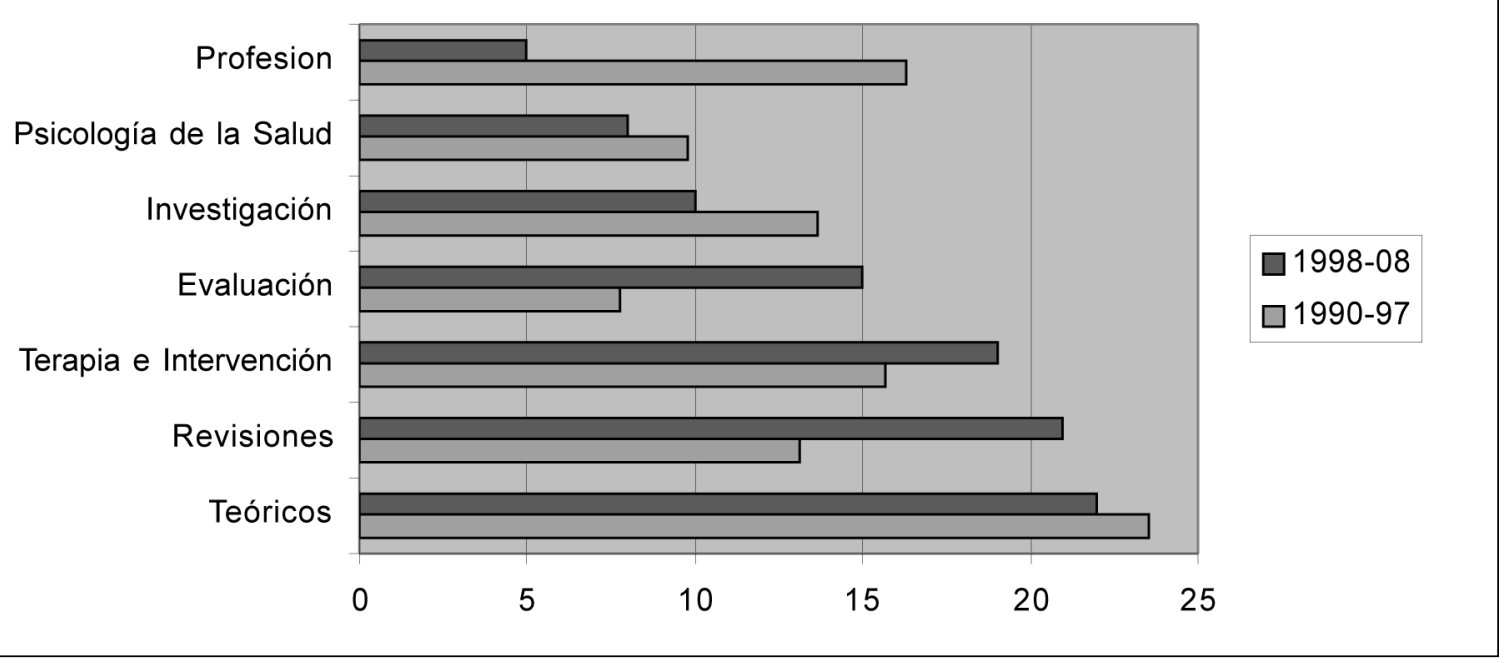

Como se observa en el gráfico precedente, la única categoría que permanece más o menos estable con respecto al periodo 1990-97 es la de "teóricos". En el resto de apartados temáticos se observan cambios más o menos drásticos. Las alteraciones son especialmente en los ámbitos de "profesión" e "investigación", donde se ha producido una reducción importante de publicaciones, así como en los de "revisiones" y "evaluación", donde el aumento de publicaciones también es notable. Por mera economía de espacio, no parece razonable introducir el desglose extenso que realizamos en su momento acerca las temáticas de los artículos publicados en Clínica y Salud por años, pero a la vista de ellos se puede afirmar que los cambios indicados son graduales y sostenidos.

\section{Índices bibliométricos a partir de IN-RECS}

En el periodo 1998-2007, que es el recogido en el Índice de Impacto de Psicología, Clínica y Salud ha recibido un total de 494 citas (44,9 de promedio). De entre ellas tan sólo 58 son autorreferencias (12\%), lo cual la sitúa muy por debajo del porcentaje de autocitación medio de las revistas de psicología españolas, que se sitúa en torno al 22\%. Entretanto, 436 de las citas recibidas son heterorreferencias de las cuales 160 se corresponden a citas internacionales (tabla 5). Los datos del índice de impacto de Clínica y Salud, así como su evolución en el universo de publicaciones de psicología españolas se muestran en el gráfico 5.

A la vista de los datos precedentes, Clínica y Salud se muestra como una publicación fuerte y consolidada, en clara línea ascendente y que raramente ha abandonado el primer cuartil de impacto en el universo de las revistas españolas de investigación psicológica, pues sólo en el periodo 200002 se movió en el entorno de las posiciones altas del segundo cuartil de citación. Más aún: al menos el $26,7 \%$ de los artículos que se publican en la revista son citados en alguna ocasión, siendo la media absoluta de citas por ítem publicado de 0,8 . 
Tabla 5. Citación de Clínica y Salud

Revistas que citan a Clínica y Salud

Psicothema
Revista Latinoamericana de Psicología
Salud Mental
Análisis y Modificación de Conducta
Revista Mexicana de Psicología
Ansiedad y Estrés
Psicología Conductual
Papeles del Psicólogo
Revista de Psicopatología y Psicología Clinica
Int. Journal of Clinical and Health Psychology
Revista de Psicología General y Aplicada
Resto

Revista Latinoamericana de Psicología

Salud Mental

27

22

Resto

Revistas a las que cita Clínica y Salud

Psicothema
Análisis y Modificación de Conducta
Papeles del Psicólogo
Psicología Conductual
International Journal of Clinical and Health Psychology
Revista de Psicología General y Aplicada
Anales de Psicología
Atención Primaria
Ansiedad y Estrés
Atención Primaria
Medicina Clínica
Revista de Psicopatología y Psicología Clínica
Intervención Psicosocial
Resto

Análisis y Modificación de Conducto

International Journal of Clinical and Health Psychology

Atención Primaria

Ansiedad y Estrés

Intervención Psicosocial

Resto

Gráfico 5. Impacto y posición interanuales de Clínica y Salud

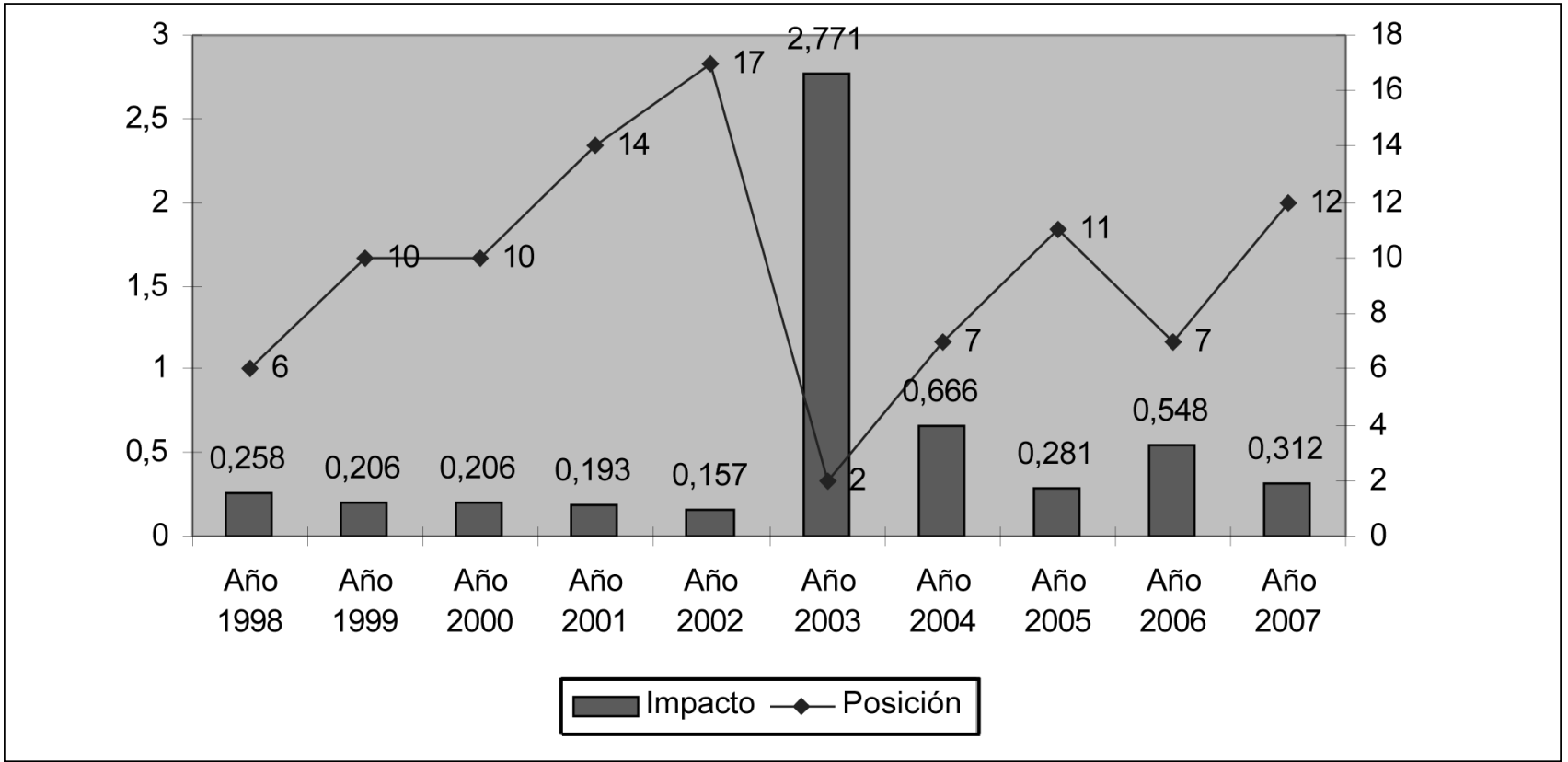

Por otra parte, las instituciones y autores que más han citado a la revista se muestran en las tablas 6 y 7 .

El gráfico 6 muestra la evolución del envejecimiento de Clínica y Salud en el tramo 2001-2007 frente al del grueso de revistas de psicología españolas durante el mismo periodo y, como puede observarse, la curva ofrece una evolución disimilar a pesar de moverse en valores del mismo entorno. Tras un envejecimiento de sus ítems menor en el 
Tabla 6. Instituciones que más referencian a Clínica y Salud en el periodo estudiado

Universidad de Granada

Universidad Complutense de Madrid

UNED

Universidad de Valencia

41

25

8

Tabla 7. Autores/as que más referencian a Clínica y Salud en el periodo estudiado

Buela Casal, Gualberto
Bretón López, Juana
Agudelo Vélez, Diana
Sanz, Jesús
Echeburúa Odriozola, Enrique
Hillers Rodríguez, Rosalía
Labrador Encinas, Francisco
Carrillo, Jesús
Barajas Martínez, S.
Sanjuán Suárez, Pilar

* Este elevado -e inusual- volumen de citas se debe a la serie de artículos de carácter bibliométrico sobre revistas de psicología clínica españolas que el equipo conformado por Buela, Bretón y Agudelo publicó en el trienio 2001-2003.

Gráfico 6. Envejecimiento de Clínica y Salud vs. Envejecimiento revistas españolas de psicología (2000-2007)

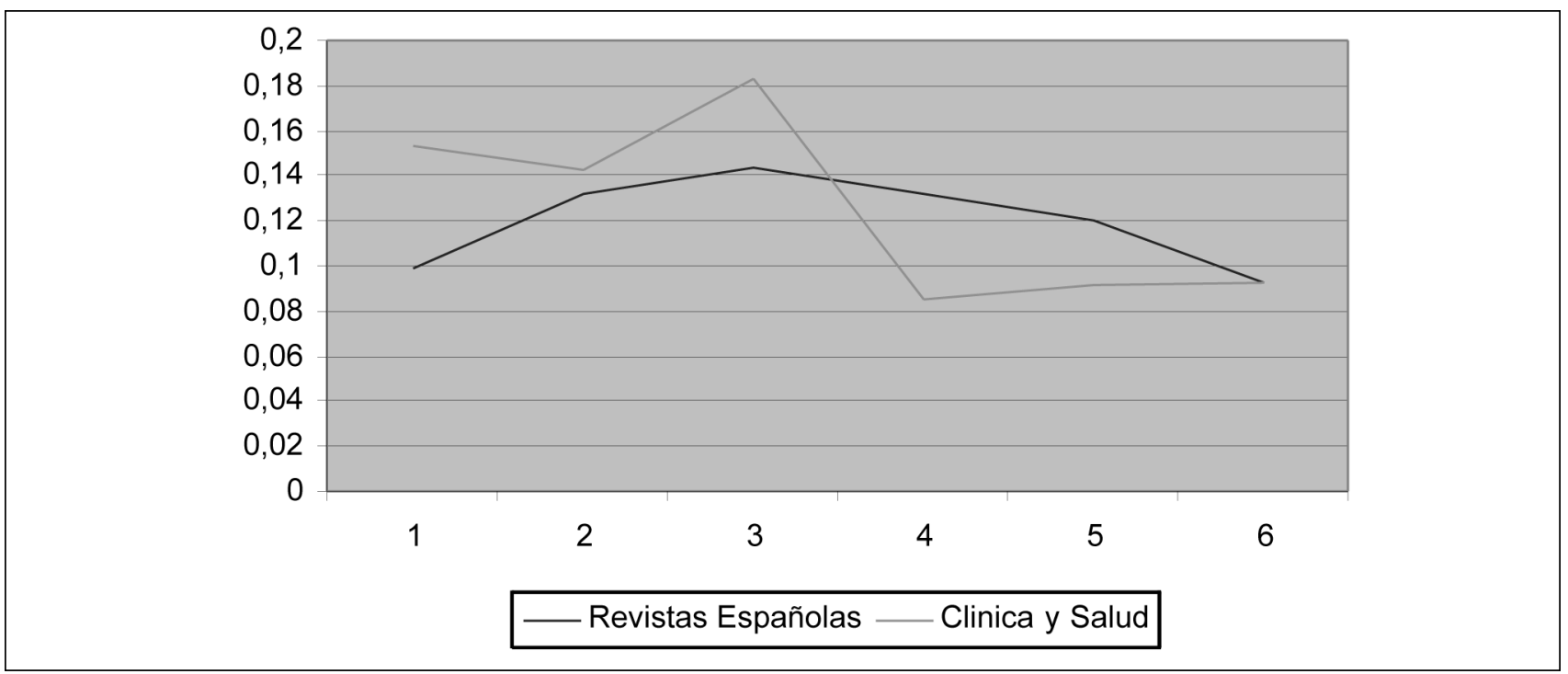

trienio 2001-2004 -préstese especial atención al pico que se registra en el año 2003 que, a la sazón, fue el de su mayor impacto-, la publicación entró en retroceso. Es interesante observar que en 2004 el porcentaje de citación disminuyó dramáticamente, pese a ser también uno de los mejores años en cuanto a impacto para Clínica y Salud. Esto se explica por varias razones, pero la principal tiene que ver con la moda. El retroceso fue generalizado entre las revistas españolas especializadas en temas propiamente clínicos frente a otras. Actualmente, se encuentra en el mismo porcentaje de citación que el conjunto de revistas con el que comparte espacio lo cual implica que ha recuperado terreno y su grado de envejecimiento es paralelo.

\section{Conclusiones}

En general, y detalles aparte que pueden ser reconsiderados por el lector a la vista de los datos ofrecidos, quisiera dedicar estas conclusiones a la perfilación de tres grandes ideas de cara al futuro de la publicación: 
1. Parece evidente, tal y como hemos ido desgranando a lo largo de este trabajo, que Clínica y Salud se perfila como un buen lugar en el que publicar en la medida que ofrece al autor un elemento decisivo en la valoración de la actividad científica en el momento actual: alta visibilidad. Y este valor, que además se muestra estable, no es fácil de obtener y preservar en un universo hiperpoblado de revistas, como lo es el de la psicología española. En consecuencia, el futuro se presenta prometedor.

2. Estamos, a raíz de lo precedente, ante una revista sólida y flexible que ha sabido adaptarse al devenir de los tiempos, como lo prueba su habilidad para ofrecer contenidos ajustados a lo que sucede lo que, en buena medida, es uno de los pilares fundamentales sobre los que se apoya su estancia prolongada en el primer cuartil de impacto. Así, mientras que en el periodo 199097, momento en el que se culminaba la consolidación de la profesión del psicólogo clínico en España, los artículos relacionados con la institucionalización profesional ocupaban un lugar importante, en el periodo 1998-08, cuando los objetivos se fueron transformado en otros más técnicos, este tipo de trabajos se vio paulatinamente reducido en beneficio de otras temáticas como, por ejemplo, las de revisión teórica y evaluación. No es menos cierto que la actividad clínica, como se ha mostrado en otros trabajos (Santolaya, Berdullas y Fernández, 2001; Pérez, 2008), es la actividad preferente del psicólogo en nuestro país y, consecuentemente, una revista como Clínica y Salud, órgano de expresión oficial -entre otros- del Colegio Oficial de Psicólogos de Madrid, tiene necesariamente que recibir una importante tasa de fidelidad entre los psicólogos.

2. Hay, no obstante y en consonancia con la última afirmación esbozada en la idea anterior, detalles curiosos que deberían servir para estimular el debate. Los datos muestran una ingente cantidad de artículos de carácter propiamente académico e investigador (revisiones teóricas, validación de instrumentos o bien análisis de trastornos y categorías clínicas), mientras que parece existir poca presencia de la profesión en cuanto tal: pocos estudios de casos, informes sobre servicios, escasos trabajos propiamente relacionados con la psicología de la salud y, en general, un muy reducido número de artículos enlazados con el día a día de la actividad del psicólogo clínico. Y no deja de resultar paradójico, precisamente, para una publicación de carácter oficialista y adscrita a un colegio profesional como la que nos ocupa. Una reflexión, por cierto, que ya Aláez (1998) realizaba al finalizar el primer estudio bibliométrico de la revista.

\section{Agradecimientos}

El autor desea agradecer a Miguel Ángel Pérez Nieto sus sugerencias, apoyo e interés a lo largo de las diferentes fases de la elaboración de este trabajo.

\section{Extended Summary}

The history of the Journal Clinica y Salud began in 1990. As early as 1997 a first bibliometric analysis was published that analyzed the publication in its first stage of development. Since then, ten years have passed and we believe now is the time for a second milestone that allows us to look closely at the development that has followed the magazine after its first phase, which we may consider to be a consolidation period.

For this analysis, apart from being collected from the magazine itself, the bibliometric measure is also based on the evidence thrown up by the Impact
Index of Spanish Journals in the Social Sciences (IN-RECS in its Spanish acronym), which has begun to value data about Spanish psychology journals from 1996 and is being updated to 2007.

The data collection method was based on a review of titles, authors and keywords. Abstracts, or other complementary sources like the introductions of the papers, were used only in those cases where the principal sources for identification did not allow us to establish definite conclusions about the contents of articles. Consequently, we have followed the following steps: 
1. Counting of articles in total, and broken down by year.

2. Counting of authors and signatures.

3. Classification of papers by topics. In the first phase a comprehensive approach was taken and subsequently was reduced to a categorical framework of seven segments

4. Topics by years.

Between 1998 and 2008, Clínica y Salud published a total of 178 articles, which leads to a median of 15.4 publications per year. 383 different people have been the authors of the papers published in the period studied. There is a fairly high rate of coauthorship (2.2 authors per item published), although the number of signatures reaches 458 as a result of repetition of authorship. 57 of the authors have published more than once. Of these, 12 have published more than two papers and there are 4 authors who sign a paper on more than three occasions. In total, the 57 authors who have published more than once make up 132 of the signatures that have appeared. These data not only imply that Clínica y Salud has, as is expected in a scientific publication, a large number of passing authors, but also reproduces the general pattern of Lotka's Law. Thus, $29 \%$ of authors appear in $43 \%$ of published articles, meanwhile the remaining $71 \%$ produce only $57 \%$ of the items (graphics 2 and 3; table 1).

It should be noted at this point, as a direct result of the preceding data, that the correlation between visibility and quantity of publications is high, because five of the authors who have signed more than one article in the period studied have achieved a lot of visibility. Thus, if any of an author's articles is among the ten most cited of Clínica y Salud from 1998 , it puts the author at the front of the field research (table 2).

On the subject of published works, we can regroup them into seven main categories (table 4 , graphic 4):

1. Theoretical (reflection, conceptual, epistemological and methodological).

2. Psychological evaluation (diagnosis, application and/or validation of tests and assessment tools).

3. Therapy and clinical intervention (psychotherapy, treatment design, case studies, clinical reports, rehabilitation).
4. Research (epidemiology, experimental studies, assessment, program evaluation).

5. Health Psychology (intervention in disorders and physical states, behavioral medicine, health education, prevention programs).

6 . Reviews (clinical categories or disorder, history).

7. Professional issues (stories of professionals, training of clinical psychologists and health, intervention services, interdisciplinary, institutional documents).

The only category that remains more or less stable with respect to the period 1990-97 is "theoretical". In the other thematic sections changes are observed to a greater or lesser extent. The alterations are especially marked in the areas of "occupation" and "research" where there has been a significant reduction of publications, as well as those of "reviews" and "assessment", where the increase in publications is notable. The changes shown are gradual and sustained. In the period 1998-2007, which is reflected in the index Impact of Psychology, the journal has received a total of 494 citations (44.9 average). Of these only 58 are self-references $(12 \%)$, which places it well below the average selfcitation rate of Spanish psychology journals, which is around $22 \%$. Meanwhile, 436 of those are external reference citations, of which 160 are international events. Data rating the impact of Clínica y Salud as well as its evolution in the field of Spanish psychology publications are shown in Figure 5.

Figure 6 shows the evolution in the aging of Clínica y Salud in 2001-2007 compared to the bulk of Spanish psychology journals during the same period. The curve shows that even though values are in the same area, their evolution is not similar. After a lower aging of items in the three years 2001-2004 the peak recorded in 2003 is particularly interesting. Indeed, this was the year of most impact as then the publication went into decline. It is interesting that in 2004 the percentage of quotations fell dramatically, despite also being one of the best years in terms of impact for the journal. This can be explained by several factors, but the principal one has to do with a fashion among investigators. The decline was widespread among Spanish journals specializing in clinical topics as compared to others. 
These findings can help us to profile three ideas for the future of the publication:

1. It seems clear that Clínica y Salud emerges as a good place to publish to the extent that it offers a critical and valued element in the evaluation of scientific activity at the present time: high visibility. This value, which in addition is stable, is not easy to obtain and maintain in the crowded field of Spanish psychological publications.

2. We are dealing with a strong and flexible journal which has adapted to the evolution over time, as evidenced by its ability to deliver content tailored to what is happening at any given time. To a large extent, this is one of the fundamental pillars on which it has been able to base remaining so long in the first quartile of impact.

3. There are, however, some interesting details that should serve to stimulate discussion. The data show an enormous number of academic articles and research of an academic nature (theoretical revisions, validation of analysis tools or disorders and clinical categories), while there appears to be little presence of the profession as such: a few case studies, reports about services, few actual works related to health psychology and, in general, a very small number of items linked with the day to day activity of the clinical psychologist. This is indeed a paradoxical situation for an official publication of a professional Association.

\section{Referencias}

Aláez, M. (1998). Estudio bibliométrico de los trabajos aparecidos en Clínica y Salud. Clínica y Salud, 9, 518-509.

García-Higuera, J.A. (1997). La Sección de Psicología Clínica y de la Salud ante los retos de la profesión. Clínica y Salud, 8, 521-529.

Pérez, F. (2008). El Colegio Oficial de Psicólogos como productor de revistas científicas. Revista de Historia de la Psicología, 29, 171-183.

Santolaya, F.; Berdullas, M. y Fernández, J.R. (2001). The Decade 1989-1998 in Spanish Psychology: An Análisis of Development of Profesional Psychology in Spain. The Spanish Journal of Psychology, 4, 237-252.

Artículo recibido: 23/12/2009

Revisión recibida: 27/01/2010

Manuscrito aceptado: 15/02/2010 